\section{I.Й. Сидорчук,}

Л.I. Сидорчук,

С.А. Левицька,

P.I. Сидорчук,

\section{Л.П. Сидорчук,}

\section{А.С. Сидорчук}

Буковинський державний медичний університет, м.Чернівці

\author{
ФАГОЦИТАРНА I СЕКРЕТОРНА \\ АКТИВНІСТЬ НЕЙТРОФІЛІВ I \\ МОНОЦИТІВ ПЕРИФЕРІЙНОÏ КРОВІ \\ ПАЦІЕНТІВ ІЗ СИНДРОМОМ ХРОНІЧНОÏ \\ ВТОМИ
}

Ключові слова: синдром хронічної втоми, нейтрофіли $і$ моноцити, фагочитоз, цитокіни.
Резюме. Проведене дослідження фагоцитарної активності та продукиї циитокінів нейтрофілами і моноцитами у 35 пацієнтів із синдромом хронічної втоми. Розвиток синдрому хронічної втоми асоиіюе із зниженням фагоцитарної активності та фагоциттарного індексу при зростанні продукиії IL-1, IL-6, IL-8, фактору некрозу пухлин альфа та інтерферону альфа.

\section{Вступ}

В імунній відповіді бере участь цілий ряд клітин і біологічно активних речовин (цитокінів). Центральна роль на перших етапах імунної відповіді належить найбільш чисельній групі імунокомпетентних клітин - лейкоцитам [8]. Надзвичайно важливою групою клітин, здатних до фагоцитозу, є популяція мононуклеарних фагоцитів - моноцитів/макрофагів. Ці клітини володіють здатністю щодо захвату частинок, у тому числі збудників інфекційних хвороб, з подальшим ï поглинанням і руйнуванням [3]. Для виконання цих функцій моноцити стратегічно розміщуються в тих тканинах організму, де можлива інтервенція мікроорганізмів.

Друга важлива група фагоцитуючих клітин поліморфноядерні нейтрофільні гранулоцити. Нейтрофіли складають 75-90\% серед лейкоцитів крові i походять від тих самих клітинпопередників, що і моноцити/макрофаги. Подібно моноцитам нейтрофіли мігрують у тканини, відповідають на певні стимули, але на відміну від моноцитів живуть всього 2-3 дні і гинуть одразу після поглинання і руйнування ними чужорідного матеріалу [9].

Вивчення показників фагоцитозу має значення в комплексному аналізі і діагностиці імунодефіцитних станів, дисфункції імунної системи [4]. У зв'язку із участю фагоцитуючих клітин в елімінації імунних комплексів, тісним зв'язком інтенсивності фагоцитозу з активністю компонентів системи комплементу, концентрацією іму- ноглобулінів $\mathrm{G}(\operatorname{IgG})$, наявністю інших опсонізуючих факторів, дослідження активності фагоцитозу відіграє важливу роль у діагностиці, оцінці патогенезу захворювання, ефективності патогенетичної терапії [5]. Найінформативнішими для оцінки активності фагоцитозу вважають фагоцитарне число, кількість активних фагоцитів, їх секреторну активність.

\section{Мета дослідження}

Встановити фагоцитарну активність моноцитів і нейтрофілів та їх секреторну активність щодо цитокінів першого і другого покоління в пацієнтів із синдромом хронічної втоми (CXB).

\section{Матеріал і методи дослідження}

Під спостереженням знаходилися 35 пацієнтів у віці 30-45 років з чіткими ознаками СХВ. Як контроль використовували периферійну кров 29 донорів віком 25-40 років. Термін спостереження за хворими тривав від 3 до 5 років, при цьому 1-2 рази на рік у пацієнтів проводилося клінікоімунологічне обстеження.

Популяцію нейтрофілів периферійної крові пацієнтів отримували за допомогою центрифугування на подвійному градієнті щільності 1,093 фікол-верографіну [10]. Моноцити із периферійної крові пацієнтів виділяли за методом H.R.Recalde [7].

Фагоцитарну активність нейтрофілів і моноцитів периферійної крові визначали чашковим методом [1].

Вміст інтерлейкінів (IL-1, IL-6, IL-8), фактору 
некрозу пухлин альфа (ФНП-а) та інтерферону альфа (ІФН-а) визначали в супернатантах нейтрофілів і моноцитів, одержаних після центрифугування, імуноферментним методом з використанням тест-систем виробництва фірми R\&D Systems (USA).

Статистичне опрацювання одержаних результатів проводилося методами варіаційної статистики з визначенням достовірності різниць ознак за t-критерієм Стьюдента [2]. Статистичну обробку виконували на комп'ютері IBM Pentium IV Microsoft Excel Professional for Windows.

\section{Обговорення результатів дослідження}

Результати вивчення фагоцитарної активності нейтрофільних лейкоцитів і моноцитів наведені в табл. 1 .

У пацієнтів із СXВ знижена фагоцитарна активність нейтрофілів на 46,94\%, моноцитів - на $38,84 \%$. Одночасно понижується захоплююча активність фагоцитуючих клітин у пацієнтів із CXB: нейтрофілів - на 31,69\%, моноцитів - на $38,63 \%$.
Таким чином, СХВ у молодих людей супроводжується дисфункцією фагоцитарної активності нейтрофільних лейкоцитів і моноцитів на перших етапах фагоцитозу.

Існує цитокінова сигналізація, яка регулює реакції неспецифічного протиінфекційного захисту (вродженого) і адаптивного (набутого) імунітету, у тому числі реакції запалення, протибактеріального і противірусного захисту, клональної проліферації імунокомпетентних клітин та їх функцій [6].

Враховуючи важливість цитокінової регуляції нами проведені дослідження секреторної активності фагоцитуючих клітин (поліморфноядерних лейкоцитів і моноцитів) периферійної крові пацієнтів із СХВ (табл. 2).

Показано, що в пацієнтів із СХВ нейтрофіли i моноцити проявляють підвищену секреторну активність стосовно цитокінів як першого (доімунного), так і другого покоління, що засвідчує про те, що в пацієнтів із СХВ формується підвищена активація факторів і механізмів неспецифічного протиінфекційного захисту і специфічної імунної

Таблиця 1

Фагоцитарна активність нейтрофілів і моноцитів периферійної крові пацієнтів із синдромом хронічної втоми

\begin{tabular}{|c|c|c|c|c|c|c|}
\hline $\begin{array}{c}\text { Фагоци- } \\
\text { туючi } \\
\text { клітини }\end{array}$ & Показники & $\begin{array}{c}\text { Одиниці } \\
\text { виміру }\end{array}$ & $\begin{array}{c}\text { Практично } \\
\text { здорові } \\
\text { особи } \\
\text { (контроль) } \\
\text { (n=29) }\end{array}$ & $\begin{array}{c}\text { Паціснти із } \\
\mathbf{C X B} \\
\text { (n=35) }\end{array}$ & $\begin{array}{c}\text { Ступінь } \\
\text { імунних } \\
\text { порушень }\end{array}$ & P \\
\hline $\begin{array}{c}\text { Нейт- } \\
\text { рофіли }\end{array}$ & $\begin{array}{c}\text { Фагоцитарна } \\
\text { активність }\end{array}$ & $\%$ & $79,82 \pm 2,60$ & $54,32 \pm 1,47$ & $\mathrm{I}$ & $<0,01$ \\
\cline { 2 - 7 } & $\begin{array}{c}\text { Фагоцитарний } \\
\text { індекс }\end{array}$ & од & $7,73 \pm 0,27$ & $5,87 \pm 0,87$ & $\mathrm{I}$ & $<0,05$ \\
\hline $\begin{array}{c}\text { Моноци } \\
\text {-ти }\end{array}$ & $\begin{array}{c}\text { Фагоцитарна } \\
\text { активність }\end{array}$ & $\%$ & $76,93 \pm 2,32$ & $55,41 \pm 1,51$ & $\mathrm{I}$ & $<0,01$ \\
\cline { 2 - 7 } & $\begin{array}{c}\text { Фагоцитарний } \\
\text { індекс }\end{array}$ & од & $\mathbf{8 , 4 7 \pm 0 , 3 1}$ & $6,11 \pm 0,22$ & $\mathrm{I}$ & $<0,01$ \\
\hline
\end{tabular}

Таблиця 2

Секреторна активність нейтрофільних лейкоцитів і моноцитів периферійної крові пацієнтів із синдромом хронічної втоми

\begin{tabular}{|c|c|c|c|c|c|c|}
\hline $\begin{array}{c}\text { Фагоци- } \\
\text { туючі } \\
\text { клітини }\end{array}$ & Цитокіни & $\begin{array}{c}\text { Одиниці } \\
\text { виміру }\end{array}$ & $\begin{array}{c}\text { Практично } \\
\text { здорові } \\
\text { особи } \\
(\text { контроль) } \\
(\mathbf{n}=29)\end{array}$ & $\begin{array}{c}\text { Паціснти із } \\
\text { CXB } \\
(\mathbf{n}=\mathbf{3 5})\end{array}$ & $\begin{array}{c}\text { Ступінь } \\
\text { імунних } \\
\text { порушень }\end{array}$ & $\mathbf{P}$ \\
\hline \multirow{4}{*}{$\begin{array}{c}\text { Нейтрофі- } \\
\text { ли }\end{array}$} & IL-6 & пг/мл & $3,51 \pm 0,11$ & $4,98 \pm 0,19$ & II & $<0,01$ \\
\hline & IL-8 & пг/мл & $2,59 \pm 0,12$ & $4,03 \pm 0,18$ & II & $<0,01$ \\
\hline & ФНП- $\alpha$ & пг/мл & $4,34 \pm 0,21$ & $6,11 \pm 0,25$ & II & $<0,01$ \\
\hline & IФH- $\alpha$ & пг/мл & $5,18 \pm 0,22$ & $5,78 \pm 0,20$ & I & $<0,05$ \\
\hline \multirow[t]{5}{*}{ Моноцити } & IL-1 & пг/мл & $16,01 \pm 0,61$ & $21,69 \pm 0,87$ & II & $<0,01$ \\
\hline & IL-6 & пг/мл & $4,76 \pm 0,24$ & $6,87 \pm 0,32$ & II & $<0,01$ \\
\hline & IL-8 & пг/мл & $3,03 \pm 0,09$ & $4,17 \pm 0,17$ & II & $<0,01$ \\
\hline & ФНП- $\alpha$ & пг/мл & $6,26 \pm 0,21$ & $9,03 \pm 0,36$ & II & $<0,01$ \\
\hline & IФH- $\alpha$ & пг/мл & $8,39 \pm 0,33$ & $9,54 \pm 0,43$ & I & $<0,05$ \\
\hline
\end{tabular}


відповіді на антиген.

У нейтрофільних поліморфних лейкоцитів посилюється секреція IL-6 на 41,88\%, IL-8 - на $55,60 \%$, ФНП-а - на 40,78\%. Незначно (на $11,58 \%$ ) зростає продукція ІФН-а, що може свідчити про наявність вірусної інфекції в пацієнтів із CXB.

Суттєве $(\mathrm{p}<0,05-0,01)$ зростання секреторної активності нейтрофільних лейкоцитів щодо продукції цитокінів першого і другого покоління свідчить про активацію в пацієнтів із СXВ факторів і механізмів неспецифічного та специфічного імунного захисту та є доказом на користь дисфункції імунної системи в пацієнтів із СХВ.

Підтвердженням цього є активація секреторної функції моноцитів щодо продукції цитокінів першого і другого порядку. Так, продукція IL-1 моноцитами периферійної крові пацієнтів із СХВ зростає на $35,48 \%$, IL-6 - на 44,33\%, IL-8 - на $37,62 \%$, фактору некрозу пухлин - альфа - на $44,25 \%$ та альфа-інтерферону- на $13,71 \%$.

Одержані результати з вивчення фагоцитарної активності нейтрофілів і моноцитів периферійної крові пацієнтів із СХВ погоджуються з даними більшості досліджень у тому, що СХВ - це синдром дисфункції імунної системи із порушенням факторів і механізмів неспецифічного протиінфекційного захисту. Підвищення секре-торної активності стосовно імунорегуляторних медіаторів підтверджує концепцію про наявну асоціацію між розвитком СХВ і перенесеним маніфестним інфекційним захворюванням або ж латентною інфекцією.

\section{Висновки}

1. У пацієнтів із синдромом хронічної втоми має місце зниження фагоцитарної активності нейтрофів і моноцитів периферійної крові на 46,94\% і 38,84\% відповідно, а також зменшення фагоцитарного індекса - на 31,69\% і 38,63\% відповідно.

2. Секреторна активність нейтрофілів і моноцитів периферійної крові пацієнтів із синд-ромом хронічної втоми підвищується щодо продукції цитокінів першого і другого порядку залежно від імунокомпетентної клітини та цитокіну.

\section{Перспективи подальших досліджень}

Одержані результати $є$ підставою для оптимізації імунотерапевтичної тактики ведення пацієнтів із синдромом хронічної втоми.

Література. 1. Дуглас С.Д. Исследование фагоцитоза в клинической практике: перевод с англ. / С.Д.Дуглас, П.Г.Кун. - М.: Медицина, 1983. - С.63-64, 87-88. 2.
Сергиенко В.И. Математическая статистика в клинических исследованиях / В.И.Сергиенко, И.Б.Бондарева. - М.: ГЭОТАР-МЕД, 2001. - 256 с. 3. Blood monocyte count may be a predictor of vascular access failure in hemodialysis patients / A.Tanaka, Y.Ito, T.Tanaka [et al.] // Ther Apher Dial. - 2013. Vol.17(6). - P.620-624. 4. Futosi K. Reprint of Neutrophil cell surface receptors and their intracellular signal transduction pathways / K.Futosi, S.Fodor, A.Mocsai // Int Immunopharmacol. - 2013. - Vol.17(4). - P.1185-1197. 5. Gorgens A. New relationships of human hematopoietic lineages facilitate detection of multipotent hematopoietic stem and progenitor cells / A.Gorgens, S.Radtke, P.A.Horn, B.Giebel // Cell Cycle. - 2013. - Vol.15. - P.3478-3482. 6. Janeway Ch. Immunology (the immune system in health and disease) / Ch.Janeway, P.Trawers, M.Shlomchik // - New York: Gerland Science Publishing, 2005. - 820 p. 7. Recalde H.R. A simple method of obtaining monocytes in suspension / H.R.Recalde // J. of Immunological Methods. - 1994. - V.69. - P.71-77. 8. The neutrophil lymphocyte ratio may be useful inflammatory indicator before applying other expensive and invasive procedures/ S.Demirkol, S.Balta, U.Kucuk [et al.] // Indian J Ophthalmol. - 2013. - Vol.61(11). - P.685. 9. Virus dosedependent neutrophil and lymphocyte proportions in peripheral blood during influenza A infection of mice / F.Kostolansky, V.Dugovicova, J.Janulikova [et al.] // Acta Virol. - 2013. - Vol.57(4). - P.474-476. 10. Wang J.S. Systemic hypoxia enhances bacterial activities of human polymorphonuclear leucocytes / J.S. Wang, H.C.Liu // Clin. Sci (Lond). 2009. - V.116(11) - P.805-817.

\section{ФАГОЦИТАРНАЯ И СЕКРЕТОРНАЯ АКТИВНОСТЬ НЕЙТРОФИЛОВ И МОНОЦИТОВ ПЕРИФЕРИЧЕСКОЙ КРОВИ ПАЦИЕНТОВ С СИНДРОМОМ ХРОНИЧЕСКОЙ УСТАЛОСТИ}

\section{И.Й.Сидорчук, Л.И.Сидорчук, С.А.Левицкая, Р.И.Сидорчук, Л.П.Сидорчук, А.С.Сидорчук}

Резюме. Проведено исследование фагоцитарной активности и продукции цитокинов нейтрофилами и моноцитами у 35 пациентов с синдромом хронической усталости. Развитие синдрома хронической усталости ассоциирует со снижением фагоцитарной активности и фагоцитарного индекса при росте продукции IL-1, IL-6, IL-8, фактора некроза опухолей альфа и интерферона альфа.

Ключевые слова: синдром хронической усталости, нейтрофилы и моноциты, фагоцитоз, цитокины.

\section{THE PHAGOCYTIC AND SECRETORY ACTIVITY OF MONOCYTES AND, NEUTROPHILLS IN PERIPHERAL BLOOD OF PATIENTS WITH CHRONIC FATIGUE SYNDROME}

\section{Y.Sydorchuk, L.I.Sydorchuk, S.A.Levytska, R.I.Sydorchuk,} L.P.Sydorchuk, A.S.Sydorchuk

Abstract. Investigation of phagocytic activity and cytokine production by monocytes and neutrophils has been carried out in 35 patients with chronic fatigue syndrome. Chronic fatigue syndrome is associated with a decrease of phagocytic activity and phagocytic index and at increase of the production of IL-1, IL-6, IL-8, tumor necrosis factor alpha and interferon alpha.

Key words: chronic fatigue syndrome, neutrophils, monocytes, fagocytosis, cytokines.

Bukovyna State Medical University (Chernivtsi) Clin. and experim. pathol.- 2014.- Vol.13, №1 (47).-P.126-128. Надійшла до редакиії 10.02.2014

Реиензент - проф. С.С. Дейнека

() І.Й. Сидорчук, Л.I. Сидорчук, С.А. Левичька, Р.І. Сидорчук, Л.П. Сидорчук,А.С. Сидорчук, 2014 